\title{
マグネシウムの靶性・延性に及ぼす添加元素の影響
}

\author{
染川英俊
}

\author{
国立研究開発法人 物質・材料研究機構＼cjkstart構造材料研究拠点
}

\author{
J. Japan Inst. Met. Mater. Vol. 83, No. 3 (2019), pp. 65-75 \\ C) 2019 The Japan Institute of Metals and Materials \\ Review
}

\section{Effect of Alloying Elements on Toughness and Ductility of Magnesium}

Hidetoshi Somekawa

Research Center for Structural Materials, National Institute for Materials Science, Tsukuba 305-0047

Development of magnesium alloys, which exhibit high strength and high ductility (fracture toughness), is critical for ensuring safety and reliability in structural applications. It is well-known that grain refinement and/or alloying are impressive strategies to attain such properties in metallic materials. In the former case, grain boundaries of magnesium and its alloys have unique characteristics, e.g., sites for non-basal dislocation activity and occurrence of partial grain boundary sliding. As a result, strength as well as ductility (fracture toughness) tend to increase and improve with grain refinement. In the latter case, 29 types of solid solution elements, which have a maximum solubility of more than 0.1 at \%, can dissolve in magnesium. Several elements are generally added to magnesium simultaneously to achieve good mechanical properties via a synergistic effect. In industrial fields, ternary magnesium alloys such as $\mathrm{Mg}-\mathrm{Al}-\mathrm{Zn}$ and $\mathrm{Mg}-\mathrm{Zn}-\mathrm{Zr}$ alloys, which have finegrained structures, have been widely used; however, there is no still clear and systematic understanding of the impact of various alloying elements on properties for magnesium. In this paper, we review recent results on the effect of solid solution alloying elements on ductility (fracture toughness), with focusing on polycrystalline binary magnesium alloys. Regarding the toughness, crack-propagation behavior and/or fracture behavior are quite sensitive to the alloying element, regardless of the grain size. Twin boundaries in particular are recognized as harmful defects, because the act as crack-propagation site. Nevertheless, changing the electric bonding behavior through alloying has the potential to increase toughness. As for the ductility, alloying elements also dramatically affect the room-temperature plastic deformation; activation of not only non-basal dislocation slip but also grain boundary sliding plays a notable role in enhancing the elongation-to-failure in tension. [doi:10.2320/jinstmet.J2018067]

(Received December 10, 2018; Accepted December 21, 2018; Published February 18, 2019)

Keywords: magnesium, mechanical properties, grain boundary plasticity, solute elements, deformation mechanism

\section{1. 緒言}

1808 年にハンフリー・デービー(1755 年 : ジョセフ・ブ ラックという説もある)によって発見されたマグネシウムは, 日常生活で使用頻度の高い鉄鋼材料などと比較すると歴史の 浅い金属である. 2 回の大戦期では, その使用量や消費量が 急増し，1950～60 年代には，「単結晶」を用いたマグネシウ 厶の基礎研究が精力的に実施された ${ }^{1-11)}$ 。 マグネシウムに関 する結晶塑性学は, この時期にほぼ構築されたといっても過 言ではない，近年では，低密度を特徴とすることから，切迫 した地球環境問題を解決する次世代の軽量金属材料として注 目を浴びている。自動車への適用を例示すると, 車体重量を $100 \mathrm{~kg}$ 低減すると, 燃費効率が $0.9 \mathrm{~km} / \mathrm{L}$ 向上すると試算さ れ ${ }^{12)}$, 既存や新規部材をマグネシウムに代替することに よって，大きな軽量化効果が得られる，自動車に限らず，電 子機器や医療機器など多様な分野で, その適用や応用が検討 されている。

一方, 部材として使用する場合, 安全性や信頼性の確保が 重要であり，素材自身が「つよく」て「すぐに壊れない」，いわ ゆる高強度・高延性(高靯性)な特性を有することが要望され る。マグネシウムに限らず，古来より，金属材料の力学特性
を改善するために，1 種類または複数の元素を添加する「合 金化」が多用されている．Fig. 1 の周期表は，マグネシウム に固溶できる最大濃度 (=最大固溶量) と原子半径を表し, 0.1 at \%以上固溶する元素を色つきにて表示している ${ }^{13-15)}$. 29 種類の元素 (希土類元素を除くと 14 種類)が，マグネシウ ムに固溶することができ，これらの元素の組合せによって， 強度や延性・靯性をはじめとする諸特性の改善や向上が図ら れている．材料製造時の操作性や簡便性から，固溶量が大き く安価であるアルミニウムや亜鉛などが，添加元素として好 まれる傾向にある，適応事例が多岐にわたる $\mathrm{Mg}-\mathrm{Al}-\mathrm{Zn}$ 系合 金が最も良く知られ，Mg-Al-Mn 系合金および $\mathrm{Mg}-\mathrm{Zn}-\mathrm{Zr}$ 系 合金などは随所に流通がある。また，希土類元素の添加にと もない，耐熱性が向上するため， $\mathrm{Mg}-\mathrm{RE}$ 系合金は以前から 研究されている ${ }^{16)}$ ，今世紀はじめ，我が国で開発された長 周期積層型構造を発現する $\mathrm{Mg}-\mathrm{RE}-\mathrm{Zn}$ 系合金もまた，高強 度と難燃性を兼備した新規マグネシウム合金として国内外か ら注目を浴びている17,18).

翻って，合金化によって，特性高度化への最適解を導き出 すためには，各特性に対する溶質元素の影響や効果を理解す ることが重要である。マグネシウムの高強度化は，金属材料 であるが故に, 従来治金学に依拠した結晶粒サイズ微細化と 合金化にて達成され，成熟した課題と言える，最近では，大 


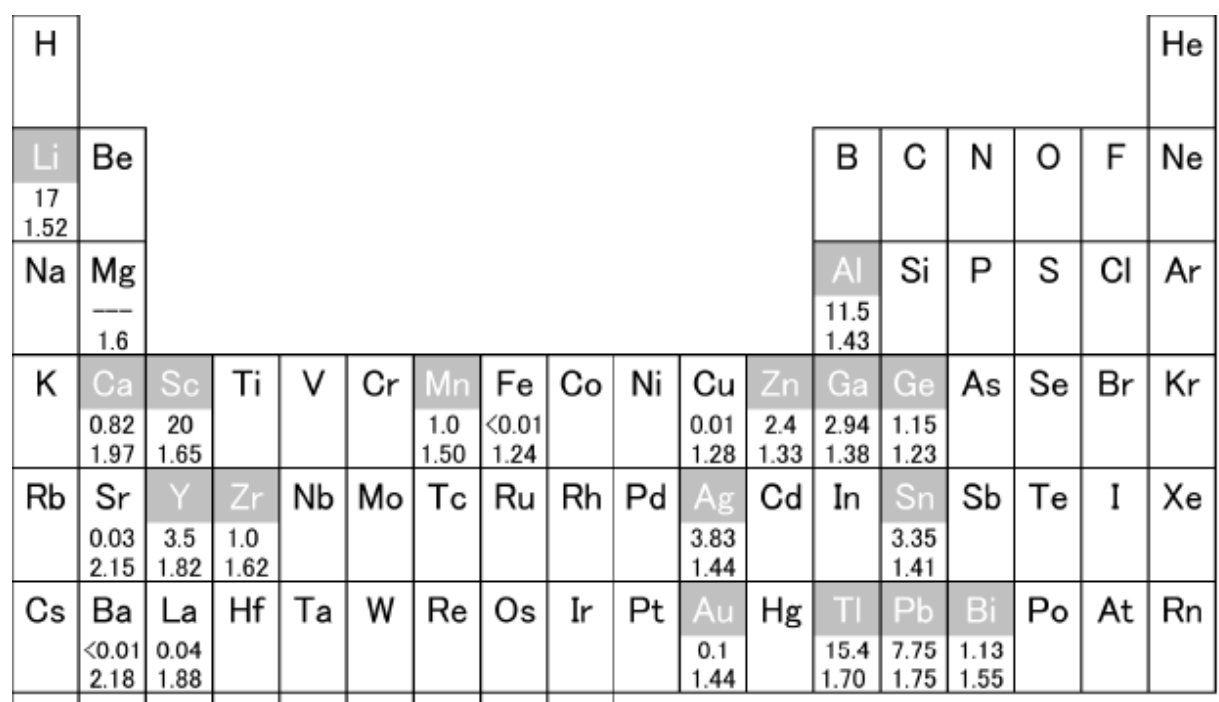

$\begin{array}{lllll}\text { Fr } & \mathrm{Ra} & \mathrm{Ac} & \text { Unq Unp Unh Uns Uno Une }\end{array}$

\begin{tabular}{|c|c|c|c|c|c|c|c|c|c|c|c|c|c|c|}
\hline La & Ce & Pr & Nd & Pm & Sm & Eu & Gd & Tb & Dy & Ho & Er & Tm & Yb & Lu \\
0.04 & 0.09 & & 0.63 & 0.76 & 0.98 & & 4.53 & 4.8 & 4.9 & 5.44 & 6.9 & 6.29 & 1.2 & 8.7 \\
1.88 & 1.83 & & 1.82 & 1.80 & 1.79 & & 1.78 & 1.76 & 1.75 & 1.75 & 1.74 & 1.76 & 1.94 & 1.73 \\
\hline Ac & Th & $\mathrm{Pa}$ & $\mathrm{U}$ & $\mathrm{Np}$ & $\mathrm{Pu}$ & $\mathrm{Am}$ & $\mathrm{Cm}$ & $\mathrm{Bk}$ & $\mathrm{Cf}$ & $\mathrm{Es}$ & $\mathrm{Fm}$ & $\mathrm{Md}$ & No & $\mathrm{Lr}$ \\
& 0.52 & & & & 1.98 & & & & & & & & & \\
\hline & 1.80 & & & & 1.64 & & & & & & & & & \\
\hline
\end{tabular}

Upper: solubility Lower: atomic radius

Fig. 1 The periodic table indicating maximum solubility $(\mathrm{mol} \%)$ to magnesium and atomic radius $\left(\times 10^{-10} \mathrm{~m}\right)^{13-15)}$. No value, i.e., a blank, indicates no data and/or no records in references and books.

規模計算機の活用により，転位運動と溶質元素との相互作用 や弾性転位論から, 高強度化に効果的な添加元素が予測, 実 証されている19-23)。他方, 延性や勒性は, 弾性変形だけな く，塑性変形の応答を含んだ特性である。また，実用/汎用 素材のほとんどは, 無数の結晶粒と結晶粒界からなる多結晶 バルク材である. 延性・鞎性の改善や向上に関して, 検討 · 考慮すべき因子が多岐にわたることから，マグネシウムに限 らず，他金属材料においても道半ばの研究課題である．本稿 では, 最近の研究報告例をもとに, 「多結晶」材料に特化し, マグネシウムおよび二元系合金の靶性と延性に対する，溶質 元素添加の効果や溶質元素機能について述べる.

\section{2. 破壊靶性と添加元素の関係}

\section{1 微細結晶粒マグネシウム合金}

マグネシウム合金およびアルミニウム合金の比強度 $(=$ 降 伏応力/密度) と破壊靶性值の関係を Fig. 2 に示す ${ }^{24)}$. マグネ シウム合金の比強度特性は, アルミニウム合金と類似するも のの, 鞁性值は半分程度である。一方, 展伸材の鞀性值は鋳 造材よりも優れ, マグネシウム合金の展伸化は, 鞀性改善に 有効な組織制御法であるといえる. 同図には，3種類の異な る結晶粒サイズからなるマグネシウム押出材の特性を表記し ているが, 結晶粒微細化にともない, 強度と鞎性は向上する 傾向にある.これは, 結晶粒サイズに起因した塑性変形メカ ニズムにある，すべり系のそしいマグネシウムでは, 塑性変 形の進行とともに, 変形を補完する変形双晶が生じる. しか し, 双晶界面は, 母相に対して幾何学的段差を作り出すた

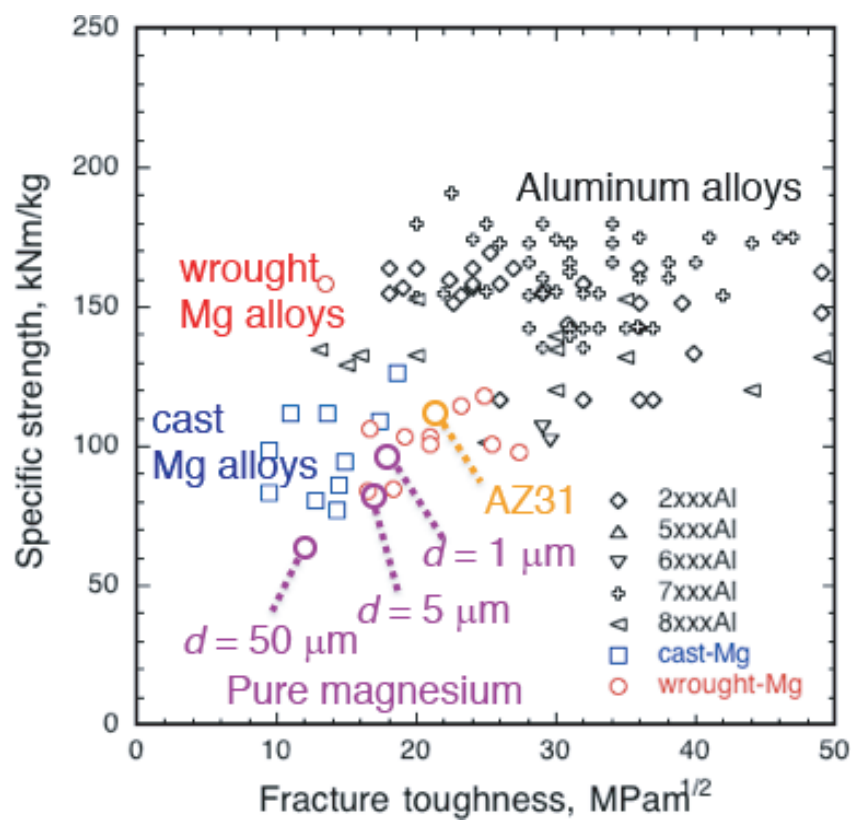

Fig. 2 Relationship between specific strength (= yield strength/density) and fracture toughness of conventional magnesium alloys and aluminum alloys. This figure also includes the results of magnesium having different grain sizes and AZ31 alloy. This figure is reconstructed in part from Ref. 24) with permission from JIM.

め, マイクロボイドなど破壊の起点となりやすい25,26)。 ま た，破壊鞁性試験に代表されるような，鋭利なき裂が試験片 に内在する場合, 母相と変形双晶の界面(近傍)がき裂の進展 経路となることも報告され27,28), 塑性変形を更に継続するた めには, 変形双晶の存在は有益ではない. 多方, 「多結晶」マ 
グネシウムの塑性変形に関する研究から, 結晶粒サイズの微 細化にともない, 非底面転位運動の活動 ${ }^{29)}$ や局所的な室温 粒界すべりなど30)，塑性変形応答に対して影響を及ぼす粒 界塑性の活性化が指摘されている。 また, 結晶粒界は, 変形 双晶と密接な関係がある. 変形双晶の核/形成サイトとなる ことや ${ }^{31,32)}$, 変形双晶の発生応力が Hall-Petch 則に従うこと も報告されている ${ }^{33-36)}$. そのため, 数ミクロン程度までの 結晶粒微細化は, 変形双晶の形成数密度を低減させる効果が あり，強度特性を損なわず，靶性改善に有効な組織制御法で ある。

Fig. 2 より, 汎用マグネシウム合金(平均結晶粒径： 15 $\mu \mathrm{m})$ である $\mathrm{Mg}-3 \mathrm{Al}-1 \mathrm{Zn}$ : 通称 AZ31 合金押出材の靯性值は, マグネシウム押出材よりも優れている.この結果は, 合金化 すなわち適切な添加元素を選択し, 組織制御することで, マ グネシウム合金の靶性が改善できることを示唆している． 3 $\mu \mathrm{m}$ 程度の平均結晶粒サイズからなる二元系合金押出材の䩲 性值を Fig. 3 に示す. マグネシウムの靶性值は, 添加元素の 種類によって変化する. 鞀性值は, 変形双晶の形成や分散度 合いなどに影響を受ける。しかし, Fig. 3 に示す微細粒バル ク材の場合, 変形双晶の形成は, 粒界塑性の活性化にとも なって抑制される傾向にあり ${ }^{37)}$, 靯性值への影響因子とし て考えにくい. 破壊形態やき裂進展挙動に関する観察よ $\eta^{38)}$ ，靯性值の低い $\mathrm{Mg}-\mathrm{Ca}$ 合金のき裂は，結晶粒界を進展 する割合が多く，その破壊形態は，粒界破壊に類似する。ま た， Mg-Y 合金を用いたその場 TEM 観察では，き裂が結晶 粒界を伝播することも捉えている ${ }^{39)}$ 。他方，マグネシウム と比べて鞎性值が比較的高い $\mathrm{Mg}-\mathrm{Al}$ 合金や $\mathrm{Mg}-\mathrm{Zn}$ 合金は, 結晶粒内がき裂進展経路となり，延性破壊に似た様相を示 す.

金属材料の粒界破壊は，粒界偏析に起因することが多 く40,41)，マグネシウム合金の粒界偏析も数多く報告されてい る ${ }^{42-48)}$. 経験則から, 粒界偏析に影響を及ぼす因子として, 母相原子と溶質原子とのミスフィット因子 ( = 原子半径差)が しばしば使用され，ミスフィット因子の大きな溶質原子は, 粒界偏析が起こりやすい傾向にある49,50)。 マグネシウムに適

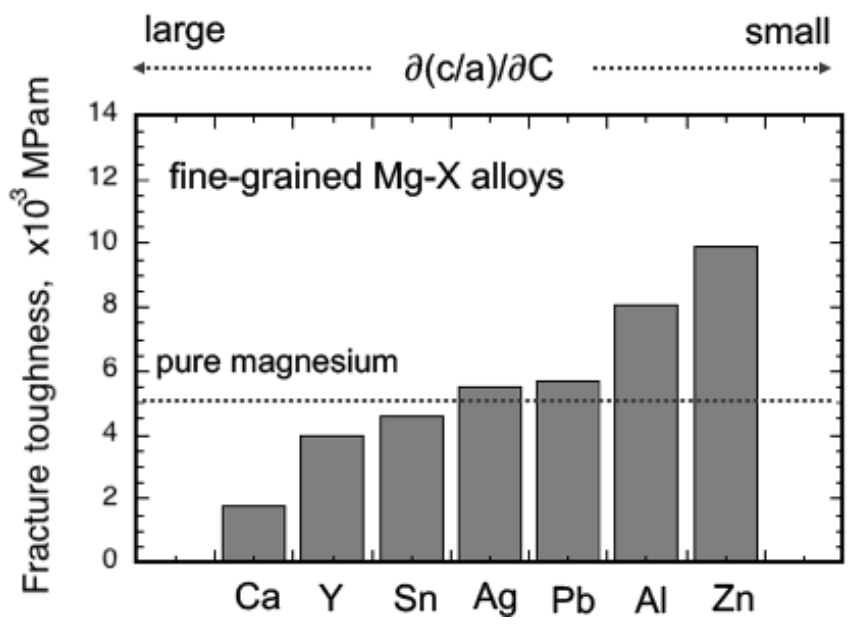

Fig. 3 Fracture toughness obtaining from fine-grained magnesium binary alloys ${ }^{38)}$. The value of $\partial(c / a) / \partial \mathrm{C}$ indicates the change in lattice parameter $c / a$ ratio with solute concentration in each element $^{52,53)}$.
用すると，アルミニウムおよびイットリウムのミスフィット 因子は，それぞれ $-11 \%,+11 \%$ と絶対值は同じである。し かし, 両二元系合金の勒性值や破壊形態は大きく違ってお り, ミスフィット因子を用いて議論, 検討することは難し い. これは, 純金属状態と合金化状態の原子半径が異なるこ とが要因と考えられる．例えば，アルミニウムと銀の原子半 径はほぼ同じ $0.143 \mathrm{~nm}, 0.144 \mathrm{~nm}$ であるが(Fig. 1)，マグネ シウム固溶時の体積ミスフィットは, $\mathrm{Mg}-\mathrm{Al}$ : $-35.8 \%$, $\mathrm{Mg}-\mathrm{Ag}$ ：-63.4\%である ${ }^{51)}$.

六方晶金属の格子面間隔 (c 軸および $\mathrm{a}$ 軸の格子定数) は, 添加元素や濃度に影響を受ける物理定数として知られてい る $^{52,53)}$. ミスフィット因子の代替ならびに溶質原子の影響を 簡略化/規格化するため, ここでは, 添加量に対して格子定 数の $c / a$ 軸比の変化を表記した $\partial(c / a) / \partial \mathrm{C}(=c / a$ 軸比の濃度 変化率)を用いることとする．Fig. 3 より，二元系合金の鞀 性值は, 添加元素の $\partial(c / a) / \partial \mathrm{C}$ と相関性をなしている. マグ ネシウムの格子定数 $(c / a$ 軸比 $)$ をきく変化させる働きのあ る元素, 例えば希土類元素やカルシウムは, 勒性改善への寄 与が小さい。これらの元素は，粒内だけでなく粒界近傍でも 大きな格子面間隔ひずみ (格子ミスマッチ)を引き起こし，粒 界破壊を助長させるためと推測される。対して，アルミニウ ムや亜鉛は, 添加にともなう格子定数の変化が小さく, マグ ネシウムよりも高い靯性值を示す。簡便ではありながら，鞀 性改善に効果的な添加元素選択の指針として, $\partial(c / a) / \partial \mathrm{C}$ の值が提示できる.

一方で, カルシウムで例示したように，二元系合金では， 粒界脆化として作用しやすい元素であっても，他元素との複 合添加や組織制御によって，この問題を回避できることが指 摘されている．三元系や四元系などの合金化は，本稿主旨か ら逸脱するが，亜鉛などと一緒に添加し，結晶粒界上の電子 結合状態を変化させることで, 粒界脆化を抑制することがで きる ${ }^{54)}$ 。また，粒界偏析サイトとなる結晶粒界を制御する ことも有効である. 加工熱処理に由来した再結晶挙動を活用 し, 自由体積の小さな亜結晶粒界 $(=$ 結晶方位差が 15 度未 満)を大量に導入したバルク材は, 粒界偏析が抑制され, 鞀 性值が飛躍的に向上することも報告されている ${ }^{55)}$.

\section{2 粗大結晶粒マグネシウム合金}

マグネシウム合金の鞎性改善には, 変形双晶の抑制が重要 であることは，先に述べた。ここでは，粗大粒材にとって避 けることができない, 高靯化阻害因子の活用法について紹介 する．マグネシウムの変形双晶に関する研究より，\{10-12\} 双晶に代表されるようなエネルギー的に安定な双晶界面で あっても, 静的熱処理によって溶質元素が双晶界面に偏析す ることが確認されている56)。これらの双晶界面は, 高強度 化に寄与することや56-58)，ひずみ付与に対する移動度が小 さく，双晶の成長や消滅に影響を及ぼすこと ${ }^{59-62)}$, 双晶界 面に偏析する元素によってき裂伝播経路が変化することも分 かっている ${ }^{63-65)}$. Fig. 4(a) は, 変形双晶を導入後, 静的熱処 理した二元系合金(平均結晶粒サイズ：〜20 $\mu \mathrm{m}$ )の靶性值を 示している. 結晶粒サイズと元素添加濃度に起因し, 靶性值 は高くないが, Fig. 3 に示した微細粒バルク材と同様, 添加 
(a)

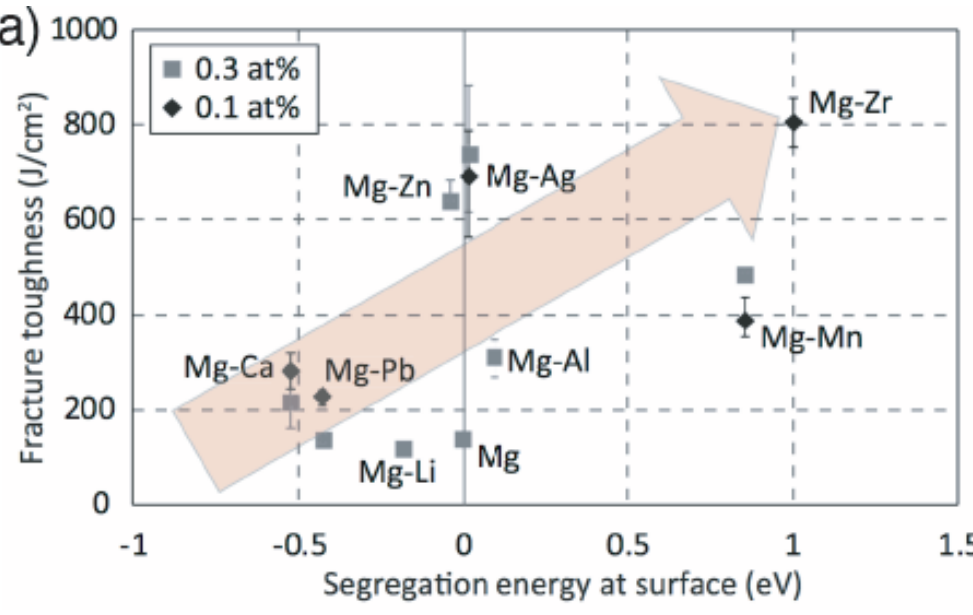

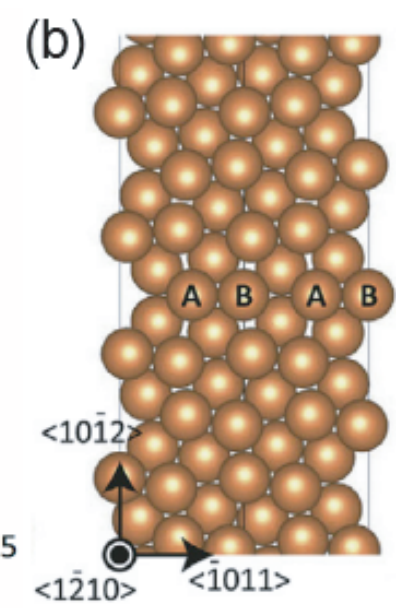
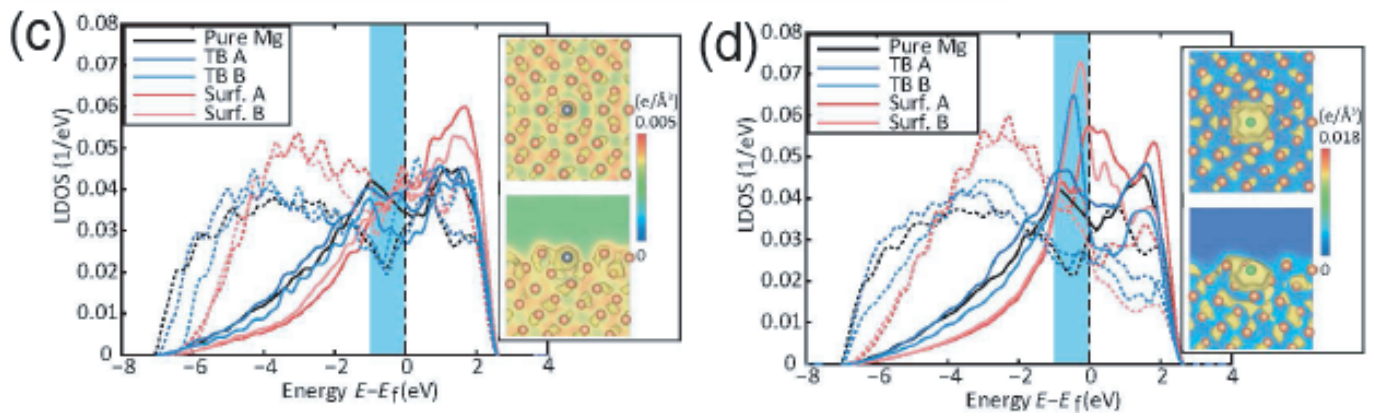

Fig. 4 (a) surface segregation energy vs. fracture toughness obtaining from meso-grained magnesium binary alloys, (b) relaxed atomic configuration of the $\{10-12\}$ twin boundary in first-principles calculation and partial charge density and LDOS of magnesium around (c) $\mathrm{Pb}$ and (d) $\mathrm{Zr}$ atom. LDOS

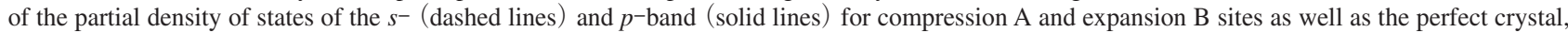
and partial charge density in the energy ranges -1 to $0 \mathrm{eV}$. This figure is reused in part of Ref. 66) with permission from Elsevier.

元素に依存する傾向にある. 変形前後のき裂伝播挙動観察よ り, 添加元素の種類によって, 伝播様相は大きく変化する. 鞁性值が高い $\mathrm{Mg}-\mathrm{Ag}$ 合金と靯性值が低い $\mathrm{Mg}-\mathrm{Li}$ 合金を比較 すると, 母相と双晶の界面(近傍)がき裂伝播経路となる割合 は, $\mathrm{Mg}-\mathrm{Li}$ 合金の方がはるかに多い. 破壊力学的モデルに 基づく粒界凝集エネルギーの観点から, 靶性值や伝播様相の 違いは, 溶質元素偏析によって生じる, 双晶界面エネルギー と表面(き裂進展にともなう新生面)エネルギーとの各変化分 に関連する，純金属状態と比較して，溶質元素偏析にともな い双晶界面エネルギーの安定化に寄与する元素, 換言すると 「表面エネルギーを不安定にする元素を添加した合金」では, 母相/双晶界面(近傍)がき裂伝播経路となりにくい66).

Fig. 4(a)の横軸は, 第一原理計算によって取得した各溶質 元素の表面偏析エネルギーを表し, 大きな值を示す元素であ るほど, 靶性值が高い傾向にある。 き裂伝播経路の観察結果 と同様に, 表面よりも双晶界面で安定化する元素が, 鞎性改 善に有効であると言える. 代表的な溶質元素(本稿では, 鉛 元素とジルコニウム元素) の双晶界面と表面に関する, 溶質 元素近傍のマグネシウムの局所電子状態密度 (LDOS : local density of state) と電荷密度図を Fig. 4(c) と (d) に示す.なお, 各溶質元素は, Fig. 4(b)に示す $\{10-12\}$ 双晶界面の最安定位 置に配置している. 靶性改善効果のそしい鉛元素の局所電子 状態密度は, マグネシウムとよく似た様相を示す。また, 溶 質元素が双晶界面または表面に存在する場合を比較しても, 局所電子状態密度や電荷密度図に大きな違いはない. 一方, ジルコニウム元素の様相は, 鉛元素やその他の溶質元素種と 異なり, $\mathrm{d}$ 軌道の価電子と $\mathrm{p}$ 軌道電子が強固な混成軌道を形
成する，表面偏析時の電荷密度図を比較例示すると，ジルコ ニウム元素が表面に存在する場合，エネルギー的に不安定で あり, マグネシウムや他の元素との差異は明瞭である ${ }^{66)}$. 粗大粒マグネシウム合金であっても，元素添加にともなう結 合状態を制御することによって，変形双晶が高靶化因子とな る可能性を秘めている.

\section{3. 延性と添加元素の関係}

\section{1 結晶粒界と粒内の変形応答}

マグネシウムおよび典型的な二元系合金の結晶粒サイズと 引張破断伸び值の関係を Fig. 5 に示す.引用した引張破断伸 びは，速度依存性を無視または低減するため，準静的ひずみ 速度下 $\left(10^{-2} \sim 10^{-4} \mathrm{~s}^{-1}\right.$ の範囲内) で取得した結果である. 押 出や圧延など, マグネシウム展伸材の延性は, 結晶構造に由 来した底面の分布状態 (集合組織)に影響を受けることが知ら れている。例えば, Equal-channel-angular extrusion：ECAE 加工によって底面配向を制御したマグネシウム合金の破断伸 びは, 従来材よりも 2 倍以上の值を示すものの ${ }^{67)}$, Fig. 5 で は, 概ね結晶粒サイズの逆数に比例する傾向にある. なお, 同図のバラツキは, 添加濃度や展伸加工法(集合組織)の違い によると思われる。ママグネシウムの結晶粒サイズを $1 \mu \mathrm{m}$ 程 度まで微細化すると, 破断伸びが $100 \%$ を超える。 また, 破 断伸びと結晶粒サイズの関係は, 添加元素の種類に依存し, マンガン元素の添加は, マグネシウムと類似した挙動を示 す. 他方, 汎用添加元素として知られるアルミニウム元素や 亜鉛元素の場合, マグネシウムと比較して, 結晶粒微細化に 

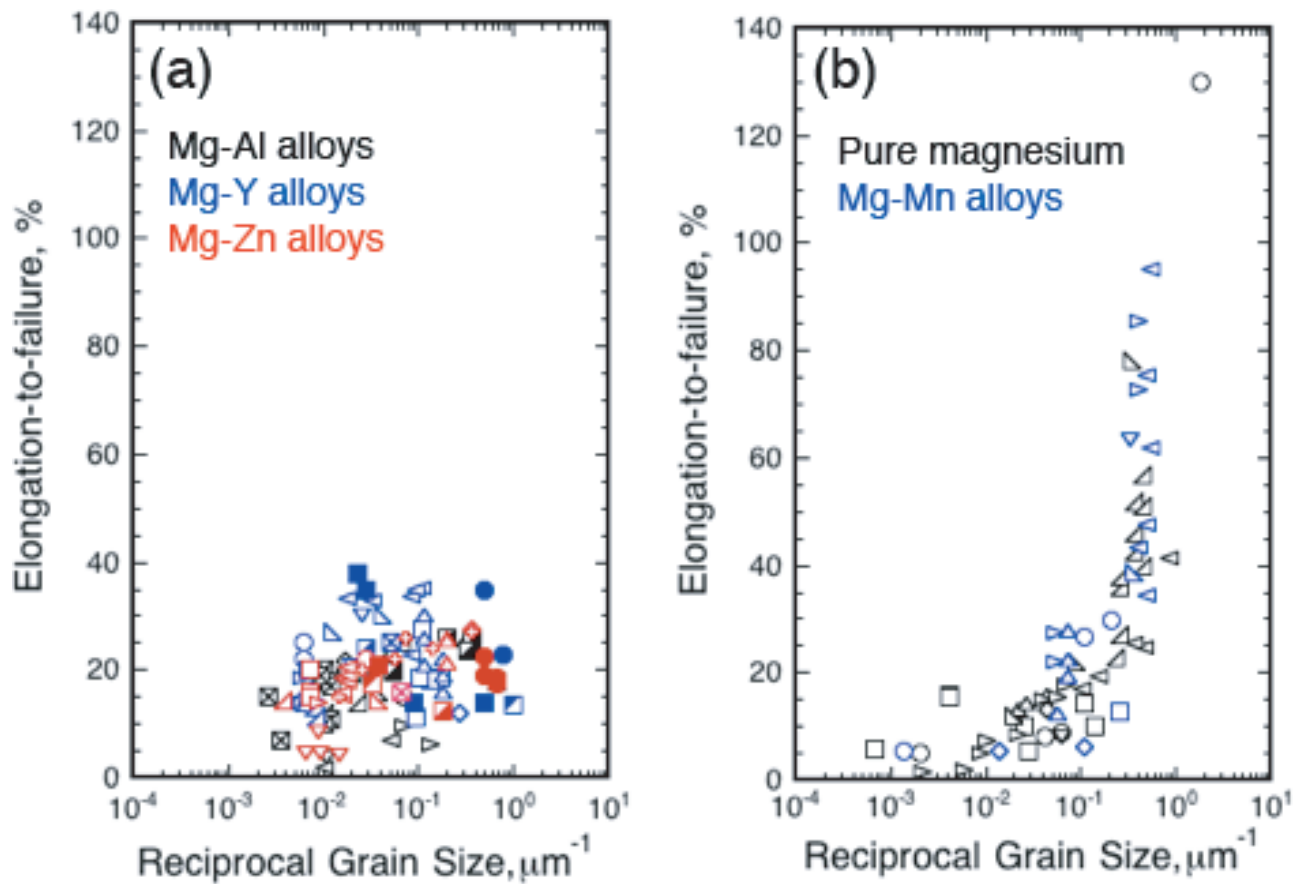

\begin{tabular}{|c|c|c|c|c|c|c|c|}
\hline 0 & [105] & [ & [115] & $\mathbf{Q}$ & [124] & $\triangleleft$ & [107] \\
\hline ㅁ & [106] & $\overrightarrow{0}$ & [116] & a & [125] & $D$ & {$[130]$} \\
\hline 0 & [107] & ㅁ & [117] & $\boldsymbol{D}$ & [48] & $\Delta$ & [131] \\
\hline$\triangle$ & [108] & 0 & [106] & e & {$[126]$} & $\Delta$ & [132] \\
\hline 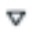 & [109] & $\Delta$ & [118] & 口 & [115] & $\mathbf{8}$ & [133] \\
\hline$<$ & [110] & $\nabla$ & [119] & 0 & {$[127]$} & a & [134] \\
\hline D & [111] & 4 & [120] & $\square$ & [116] & $\boldsymbol{\square}$ & [135] \\
\hline 8 & [112] & $D$ & [121] & 0 & [106] & e & [136] \\
\hline$\Delta$ & [113] & $\Delta$ & [122] & $\Delta$ & [128] & a & [137] \\
\hline$\otimes$ & [114] & $\Delta$ & [123] & $\nabla$ & [129] & $\phi$ & [106] \\
\hline
\end{tabular}

$\begin{array}{llllllll}\circ & {[97]} & \triangleleft & {[87]} & \square & {[145]} & \triangleright & {[82]} \\ \square & {[138]} & \triangleright & {[141]} & \diamond & {[146]} & \Delta & {[149]} \\ \diamond & {[105]} & \Delta & {[142]} & \Delta & {[147]} & & \\ \Delta & {[139]} & \Delta & {[143]} & \nabla & {[106]} & & \\ \nabla & {[140]} & \diamond & {[144]} & \triangleleft & {[148]} & & \end{array}$

Fig. 5 The variation in elongation-to-failure in tension as a function of reciprocal grain size; (a) magnesium binary alloys containing conventional alloying elements ${ }^{48,71,105-137)}$ and (b) magnesium and $\mathrm{Mg}-\mathrm{Mn}$ alloy ${ }^{82,87,97,105,106,138-149)}$.
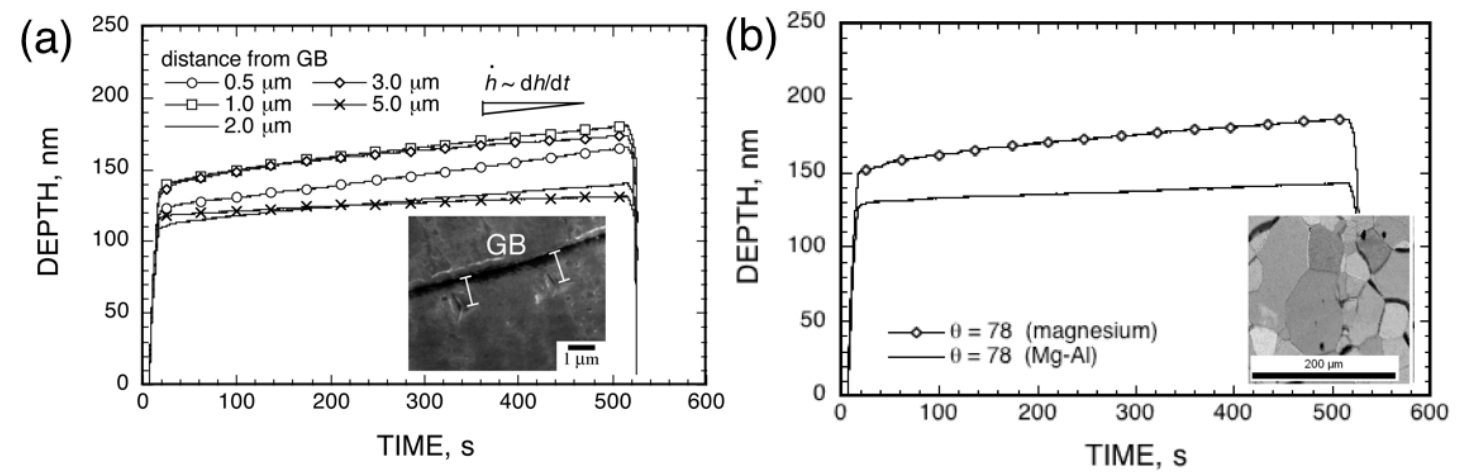

Fig. 6 The indentation depth vs. time obtaining from nanoindentation creep tests (a) in the magnesium and (b) effect of alloying elements on nanoindentation creep behavior. Inset in each image at right-side bottom indicate measurement position. This figure is reconstructed in part from Refs. 72,75) with permission from Taylor \& Francis and Elsevier, respectively.

対する延性向上への寄与は微増である。底面すべりと非底面 すべりの臨界分断せん断応力の違いを大幅に縮めると指摘さ れている希土類元素(イットリウム) も ${ }^{23,68-71)}$, 前記 2 種類の 汎用元素と同様であることは, 大変興味深く, マグネシウム の延性改善法について, 転位すべり運動のみで検討や議論す ることが難しいことを示唆している.

ここでは, まず，マグネシウムの塑性変形について，結晶 粒界近傍と結晶粒内に分類した評価事例について記す。微 小・局所変形解析が可能なナノインデンテーション法を活用 し, 押込みクリープ試験によって取得したマグネシウムの結 晶粒界(近傍) と結晶粒内の押込み変位 vs.時間曲線を Fig. 6 (a)に示す72)。押込み応答は測定箇所によって異なり，結晶 粒界近傍の押込み深さは, 結晶粒内と比較して時間経過とと もに深くなる，結晶粒界近傍であっても，測定箇所が結晶粒 界から数ミクロン程度離れることで, 押込み梁さが浅くな る. この応答様相は, 結晶粒内の計測結果と類似し, 押込み 時の変形メカニズムは, 結晶粒界から数ミクロン程度 $(=\sim 5$ $\mu \mathrm{m})$ で変化することが分かる. なお，結晶粒界からの距 離：～5 $\mu \mathrm{m}$ は, 粒界コンパティビリティが作用する限界距 離と極めて近い值である ${ }^{29)}$ 。押込みクリープ試験から得ら れた結晶粒界近傍と結晶粒内のひずみ速度感受性指数 $(m$ 值 $)$ は, 各々 $0.5, \sim 0.1$ であり, 結晶粒界近傍では, 粒界すべ 
りの活性化が推測される. 多結晶マグネシウム合金を使用し た室温引張試験であっても，局所的な粒界すべりの痕跡が確 認されていることは ${ }^{30)}$, 本結果と良い一致を示す。一方, 結晶粒内で取得した $m$ 值から, 結晶粒界近傍の粒界すべり よりも変形抵抗の大きな転位すべり運動, または, 変形双晶 が変形を担うと考えられる．粒界塑性の影響が小さな/無視 できる粗大粒マグネシウムを用いた室温クリープ試験では, 底面転位すべり運動が支配的であることも報告されてい $3^{73,74)}$.

結晶粒界近傍の局所押込みクリープ応答に及ぼす添加元 素, すなわち粒界偏析元素の効果を示すため, Fig. 6(b)に は, $\mathrm{Mg}-0.3$ at $\% \mathrm{Al}$ 合金の結晶粒界近傍の押込み変位 vs.時間 曲線も併記している ${ }^{75)}$. 計測面の結晶方位や隣接粒との結 晶方位差などは, マグネシウムと同じである。 マグネシウム の様相と異なり, $\mathrm{Mg}-\mathrm{Al}$ 合金の押达み変位量： $\Delta h$ はわずか で，マグネシウムよりも結晶粒界の変形抵抗が大きい。ま た，押込み変位量は，マグネシウム結晶粒内の計測值と同程 度であり, $\mathrm{Mg}-\mathrm{Al}$ 合金の結晶粒界近傍の主たる変形メカニ ズムは，マグネシウムの結晶粒内と同じである可能性が高 い. これらの結果は, バルク内に占める結晶粒界 $(=$ 結晶粒 サイズ)や添加元素の種類が, マグネシウムの変形メカニズ ムと極めて密接な関係があることを明示している，延性能を 付与するためには，両因子の役割を理解し，その効果的な制 御が重要である.

\section{2 引張破断伸びに及ぼす添加元素の影響}

前項に基づき，バルク内の粒界占有率が大きな微細結晶粒 二元系合金の結果を用いて, 室温延性に及ぼす合金化の効果 を述べる. Fig. 7 は, 室温で, (a) : 準静的な引張試験速度に よって得られた応力vs.ひずみ曲線, および, (b) : 破断伸び と初期ひずみ速度の関係である。比較のために, 同様の微細 組織様相からなる汎用マグネシウム合金(AZ31 合金)押出材 の結果も並記している76). 同図で引用した二元系合金の添 加濃度は 0.3 at \%である。 また, 平均結晶粒サイズが $3 \mu \mathrm{m}$ 程度で, 底面集合組織を有していることから ${ }^{77)}$, 添加元素 の違いが，変形応答の差異を反映している. Fig. 7(a)より, 破断伸びは添加元素に影響を受け, 大多数の二元系合金は, マグネシウムよりも小さい.この傾向は, Fig. 5 (a)や汎用合
金の結果に合致する。一方， $\mathrm{Mg}-\mathrm{Mn}$ 合金の破断伸びは(Fig. 7 (a))，マグネシウムの約 2 倍, AZ31 合金の 4 倍以上を呈 し，延性向上にはマンガン元素の添加が有効である. $\mathrm{Mg}-$ $\mathrm{Mn}$ 合金の破断伸びの増加は，ひずみ速度の低速化にともな い一層顕著である，例えば, ひずみ速度 : $10^{-5} \mathrm{~s}^{-1}$ で得られ た破断伸びは，室温であっても200\%を超える，翻って，他 の二元系合金の破断伸びvs.ひずみ速度の関係は, 汎用合金 と類似し，1/1000 倍低速化した引張試験条件であっても， 破断伸びの向上は数十\%程度と，その増加率は僅かである. また, Fig. 7 (a)に示す変形応答に関して, 延性改善に有効な 元素を添加した二元系合金の変形応力は, マグネシウムより も低い值を示す。一般的に，添加した溶質元素と転位すべり 運動との相互作用から, 塑性変形時の応力は純金属よりも硬 化し, 固溶強化として認知されている. しかし，優れた延性 能を有する $\mathrm{Mg}-\mathrm{Mn}$ 合金 (や $\mathrm{Mg}-\mathrm{Li}$ 合金など) は軟化傾向で あり, この現象を固溶強化によって説明することは難しい. 主変形メカニズムに依拠した詳細な要因については，次節に 記す。

\section{3 変形機構}

Fig. 8 に, 特異な延性挙動を示すマグネシウムおよび二元 系合金の Hall-Petchの関係を示す ${ }^{87)}$. 破断伸びは, 引張ひ ずみ速度に依存することから，同図では，(a)：準静的ひずみ 速度 $\left(\geq 10^{-4} \mathrm{~s}^{-1}\right)$ と, (b) : 低ひずみ速度 $\left(<10^{-4} \mathrm{~s}^{-1}\right)$ に分割し ている，準静的ひずみ速度条件下で得られる降伏応力は，従 来の Hall-Petch 則に従うが, ひずみ速度が遅い場合, 数ミク ロン程度の結晶粒サイズで，逆 Hall-Petch 則が確認できる. ニッケルや銅などでよく報告される逆 Hall-Petch 則は，結晶 粒サイズが数ナノ程度の超微細粒材で起こり, 結晶粒内に Frank-Read 源などの転位発生源が枯渇することに起因す $3^{77-80)}$. マグネシウムでは, 結晶粒サイズが 100 倍以上粗 大であっても逆 Hall-Petch 則が観察でき，その主要因が超微 細粒材と同じであるとは考えにくい. Fig. 9(a)と（b) は，低 ひずみ速度条件にて室温引張試験した後の SEM 表面観察例 である ${ }^{65)}$. 汎用合金と同程度の破断伸びを示した $\mathrm{Mg}-\mathrm{Zn}$ 合 金では，表面起伏など特異な様相は識別できない，一方，巨 大な伸びを示した $\mathrm{Mg}-\mathrm{Mn}$ 合金では，白矢印で示すように明 瞭な粒界すべりの痕跡が確認できる. Fig. 9(c) と (d)より, (a)

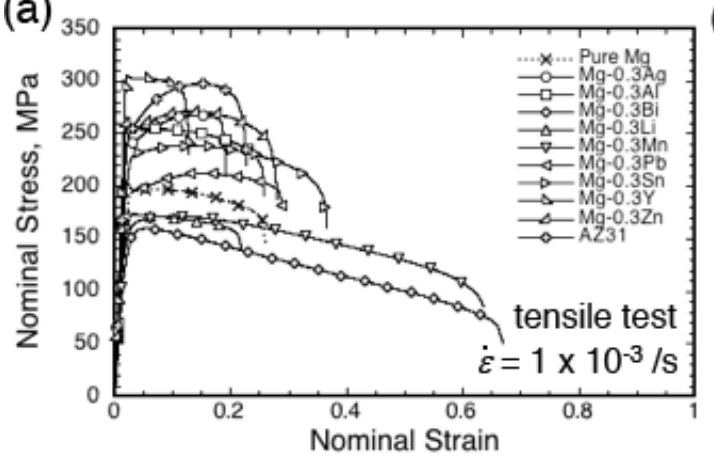

(b)

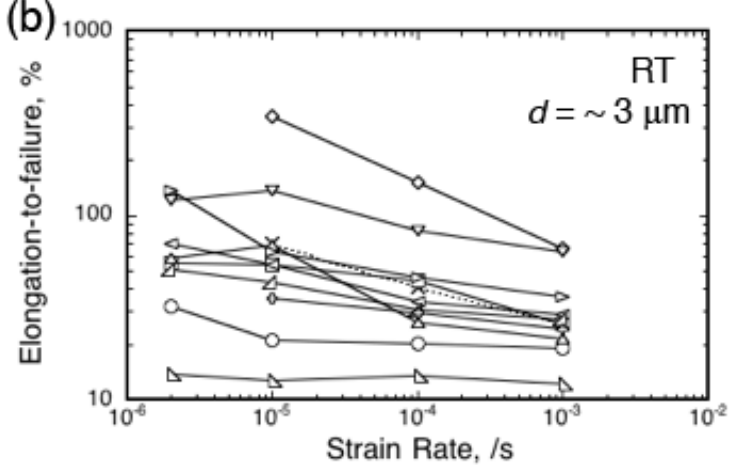

Fig. 7 Room-temperature tensile behavior in fine-grained magnesium and its binary alloys; (a) nominal stress vs. nominal strain curves at quasistatic strain rate $\left(1 \times 10^{-3} \mathrm{~s}^{-1}\right)$ and (b) variation in elongation-to-failure in tension as a function of strain rate. This figure also includes the results of fine-grained AZ31 alloy. 

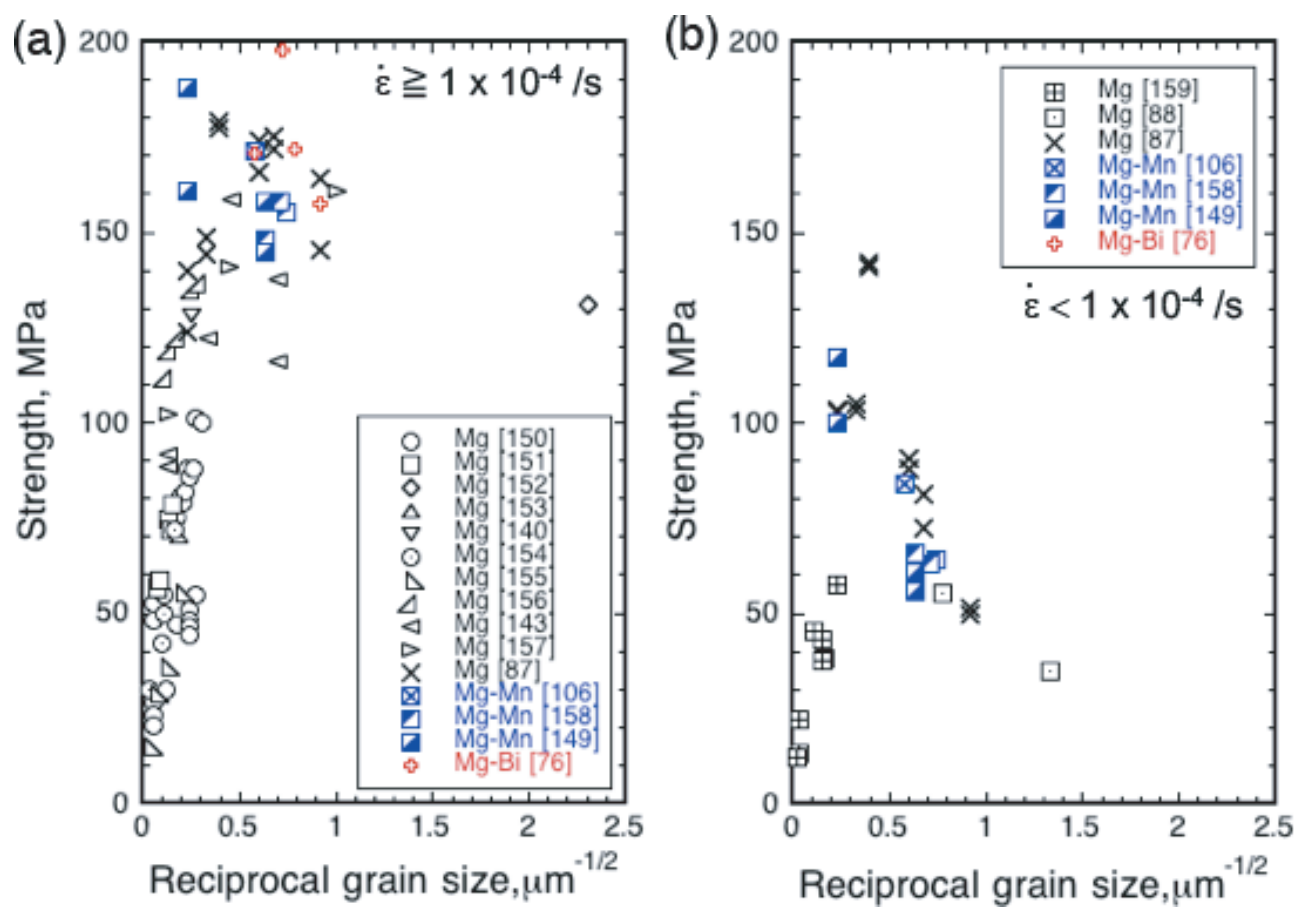

Fig. 8 Hall-Petch relation in magnesium and its binary alloys (a) at quasi-static strain rate regimes (faster than $\left.1 \times 10^{-4} \mathrm{~s}^{-1}\right){ }^{76,87,106,140,143,149-158}$ ) and (b) at low strain rate regimes (lower than $1 \times 10^{-4} \mathrm{~s}^{-1}$ ) $\left.76,87,88,106,149,158,159\right)$. This figure is reproduced in part of Ref. 87) with permission from Springer nature.
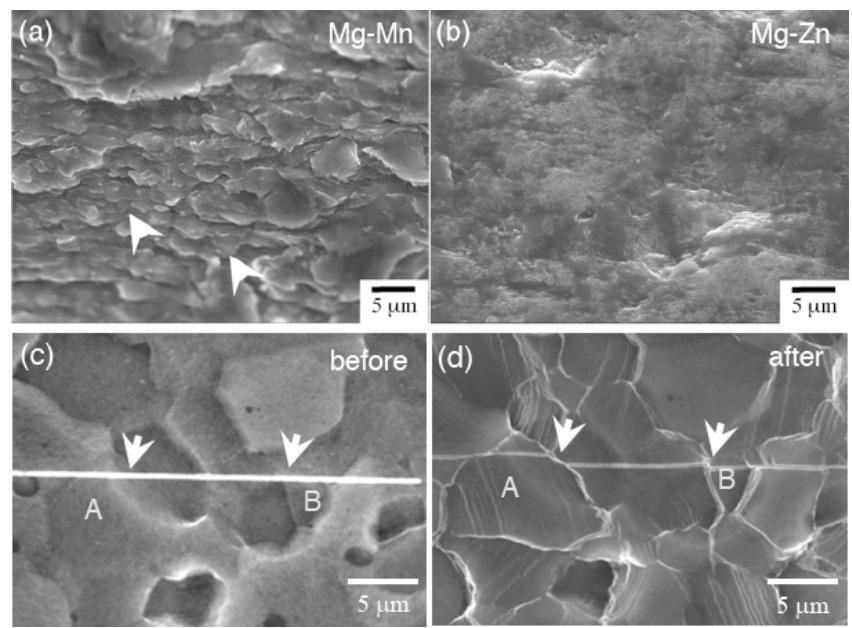

Fig. 9 Typical examples for SEM observation; after room-temperature tensile tested samples at low strain rate regimes in fine-grained (a) $\mathrm{Mg}-\mathrm{Mn}$ and (b) $\mathrm{Mg}-\mathrm{Zn}$ alloys, and difference in surface features (c) before and (d) after tensile testing in fine-grained $\mathrm{Mg}-\mathrm{Mn}$ alloy. White arrows in Fig. (a) show the trace of grain boundary sliding. In Figs. (c) and (d), white arrows and yellow characteristics correspond to the observed points/regions before and after tensile testing. Figures (a) and (b) are reused in part from Ref. 106) with permission from Taylor \& Francis.

引張試験前に導入したケガキ線は，隣接する結晶粒間で大き くずれ，試験の進行とともにずれ幅が大きくなることも確認 されている ${ }^{81)}$ 。また, 汎用および従来材の低ひずみ速度引 張試験後の破面は, 延性ディンプル形態を示すのに対し, $\mathrm{Mg}-\mathrm{Mn}$ 合金は，超塑性変形時の粒界三重点でよく形成する キャビティーに由来した破壊が生じる ${ }^{82)}$. 以上のことから, 逆 Hall-Petch 則の要因のひとつとして, 局所的な粒界すべり の発現が考えられる。

現時点では明確な解が得られていないが, 室温粒界すべり 発現の誘因について, 微視的観点から述べる. 展伸化二元系
合金の微細組織観察より，添加元素が結晶粒界に偏析するこ とは, 前記のとおり多数報告されている ${ }^{42-48)}$. 飛躍的な延 性改善のカギは, これらの偏析元素種が, 粒界すべりを活性 化させる働きがあるか否かにあると推測できる，第一原理計 算を活用した電子結合状態の検討から, 希土類元素など, 粒 界すべり促進効果のそしい元素が結晶粒界上に存在する場 合, マグネシウム電子と特定の方位に強固な非等方的結合状 態を呈する. 一方, マンガン元素は, 等方的な結合を示し, この等方/非等方性結合が, 粒界塑性に対する原子レベル的 な影響要因と勘案される ${ }^{82)}$. また, リチウム元素は, 価電 子が $\mathrm{s}$ 軌道に存在するため非局在化し, 自由電子としての挙 動が優先的に生じるためである ${ }^{83)}$.ただし, これらは一事 例に過ぎない，実際の多結晶バルク内に占める結晶粒界は, 多種多様な構造から構成されており, 数值解析時に適応や使 用するモデルも含め, 今後より詳細な議論が必要である.

Fig. 10 は, 金属材料の代表的な変形機構である, 粒界す ベり, 転位すべり運動, 変形双晶に関する流動応力 vs.ひず み速度の模式図を表し，一般的な評価速度域を網掛けで示し ている ${ }^{84)}$. 図内太線は, 支配的な変形機構の一例である. Fig. $5(\mathrm{a})$ や 7(b) で例示した汎用元素を添加したマグネシウ 厶合金の場合，低ひずみ速度域であっても破断伸びが数十\% 程度で, $m$ 值が小さいことから ${ }^{65,76)}$, これらの元素は, 室温. 粒界すべりを促進させる働きがそしいと推測できる．発現速 度が極めて遅い粒界すべりを常用の試験速度域にて捉えるこ とができず，通例の塑性変形挙動と同様に，転位すべり運動 が変形を担う。なお, 圧縮試験時は, 結晶配向と応力付与方 向との関係に起因し，流動応力は変形双晶を反映する。一 方, リチウム元素またはマンガン元素は, 粒界すべりを促進 または活性化させる効果がある。 そのため, 粒界体積の多い 微細粒バルク材では, 低速および準静的ひずみ速度域であっ 
ても局所的な粒界すべりの発現が確認できる，しかし，試験 速度の高速化にともない, 主変形機構が転位すべり運動や変 形双晶に遷移する。

微細組織構造の観点から特異二元系合金の粒界すべりの活 性化は, 粒界偏析が要因のひとつであろうことは先に述べ た，粒界すべりを促進/活性化させる元素であっても，粒界 偏析の制御は非常に重要である。バルク内に占める粒界偏析 サイトの体積率によって, 変形機構が大きく変化する. 同程 度の平均結晶サイズと添加量であっても, 自由体積の小さな 小角粒界が高密度に含有する $\mathrm{Mg}-\mathrm{Mn}$ 合金では, 破断伸びは 20〜30\%程度で, 変形応力や破断伸びはひずみ速度依存性を 示さない. また, 主変形機構は, 汎用合金と同じく転位すべ りであることが指摘されている ${ }^{85)}$.

最後に, 室温粒界すべりが発現する要因について, 緩和機 構から検証する，粒界すべりは，水飴のような巨大延性を示 す「超塑性挙動」を連想する変形機構である ${ }^{86)}$. 粒界すべり によって変形の連続性を維持するためには, 緩和機構が作用 する必要がある．金属材料のクリープ挙動を反映した構成式

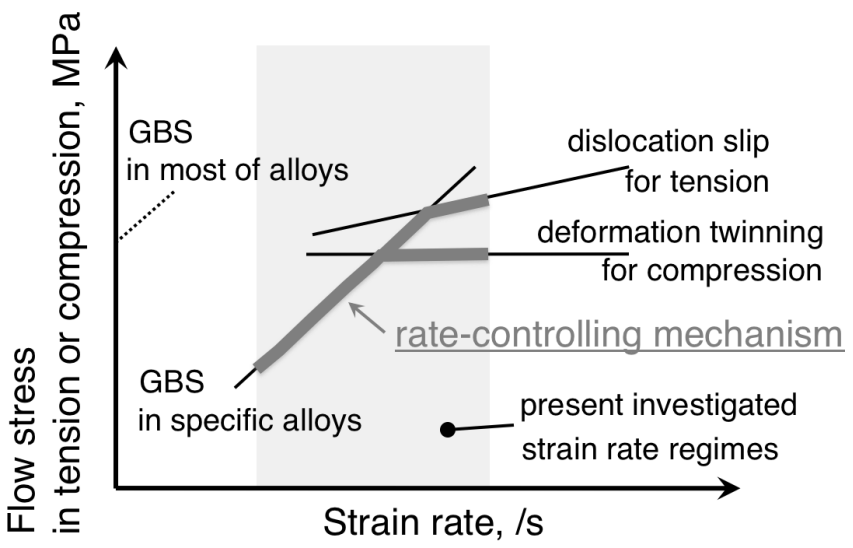

Fig. 10 The simple relation for flow stress in tension or compression vs. strain rate in the conventional and/or specific magnesium alloys at room-temperature. GBS indicates grain boundary sliding. It is noted that three different deformation mechanisms, i.e., GBS dislocation slip and twinning, depend on grain sizes and testing temperatures. This figure is reused in part from Ref. 84) with permission from JIM.
は，次式で表記される ${ }^{86)}$ 。

$$
\dot{\varepsilon}=A\left(\frac{G b}{k T}\right)\left(\frac{\sigma}{G}\right)^{n}\left(\frac{b}{d}\right)^{p} D
$$

ここで, $\dot{\varepsilon}:$ ひずみ速度, $\sigma$ : 流動応力, $G$ : 剛性率, $n:$ 応 力指数 $(=$ ひずみ速度感受性指数の逆数 $), k$ : ボルッマン定 数, $b$ : バーガースベクトル, $d:$ 結晶粒サイズ, $p:$ 粒径指 数, $D$ : 拡散係数である. マグネシウムおよびマグネシウム 合金の室温クリープ変形に関する研究報告例について Table 1 にまとめる73,76,87-95)。従来の転位すべり運動に支配された 場合 (例えば, $m<0.1$ ) と比較して, 変形機構と密接な関係 にある $m$ 值 $(=n$ 值の逆数 $)$ たは活性化体積 $: V$ は, 評価方 法に由来した差異があるものの, 概ね大きな值を示す．特 に, 結晶粒サイズの微細化やひずみ速度の低速化にともな い, $m$ 值は高い, もしくは活性化体積は小さい. 活性化エネ ルギーに関する研究報告例は数少ないが, 数十 $\mu \mathrm{m}$ 程度の結 晶粒サイズを有するバルク材では約 $20 \mathrm{~kJ} / \mathrm{mol}$ と計測されて いる ${ }^{30)}$ 。この低い活性化エネルギーより, 粒界すべりは, 転位すべりによって誘発されると指摘されている，また，結 晶粒サイズが数百 $\mu \mathrm{m}$ 以上の粗大粒材である場合, 活性化エ ネルギーは数 $\mathrm{kJ} / \mathrm{mol}$ で, 粒界近傍の原子シャッフリング機 構が粒界すべりの緩和機構であると提唱されている ${ }^{73,74,96)}$. 一方, 微細結晶粒バルク材では, 活性化エネルギーが 75〜 $85 \mathrm{~kJ} / \mathrm{mol}$ と粒界拡散に近い活性化エネルギーを示す $76,86,87)$. 前記の緩和機構と異なることを示唆し, Fig. 6(a)に示す局所 ・微小押込み応答から取得した変形機構と類似していること は興味深い. また, 結晶粒内に蓄積した弾性エネルギー解放 に起因した結晶粒回転モデルも提案されているが97), 更な る議論が必要である.

平均結晶粒サイズが, $5 \mu \mathrm{m}$ 以下からなる微細結晶粒バル ク材を用いて, ひずみ速度 : $10^{-3} \mathrm{~s}^{-1}$ 以下の引張試験の結果 をもとに，剛性率と材料定数等で規格化した関係を Fig. 11 に示す，実験条件や評価試料が多岐ではあるが，優れた破断 伸びを呈する応力 vs.ひずみ速度の関係は，一義的に集積す る傾向にある，前記のとおり，室温粒界すべりに関する緩和 機構は諸説報告, 検討されている。規格化した結果に大きな

Table 1 Results of room-temperature creep testing in various magnesium and its alloys ${ }^{73,76,87-95)}$.

\begin{tabular}{lclllr}
\hline material & grain size, $\mu \mathrm{m}$ method & $\mathrm{n}(=1 / \mathrm{m})$ or $\mathrm{V}$ & $\mathrm{Q}, \mathrm{kJ} / \mathrm{mol}$ & Ref \\
\hline Pure $\mathrm{Mg}$ & 1.2 & tensile & $\mathrm{V}=8 \mathrm{~b}^{3}\left(10^{-6}-10^{-4} / \mathrm{s}\right)$ & $84(\mathrm{RT}-323 \mathrm{~K})$ & {$[87]$} \\
Pure $\mathrm{Mg}$ & $\sim 0.5-2$ & tensile & $\mathrm{m}=0.2\left(10^{-5}-10^{-1} / \mathrm{s}\right)$ & $75(\mathrm{RT}-373 \mathrm{~K})$ & {$[88]$} \\
Pure $\mathrm{Mg}$ & 2 & tensile & $\mathrm{n}=4\left(10^{-5}-10^{-3} / \mathrm{s}\right)$ & -- & {$[89]$} \\
Pure $\mathrm{Mg}$ & $>100$ & tensile & $\mathrm{n}=3.1\left(10^{-9}-10^{-8} / \mathrm{s}\right)$ & $12(200 \mathrm{~K}-\mathrm{RT})$ & {$[73]$} \\
Pure $\mathrm{Mg}$ & 0.045 & compression & $\mathrm{n}=5\left(10^{-4}-10^{-3} / \mathrm{s}\right)$ & -- & {$[90]$} \\
Pure $\mathrm{Mg}$ & 0.06 & compression & $\mathrm{V}=12 \mathrm{~b}^{3}\left(10^{-5}-10^{-2} / \mathrm{s}\right)$ & -- & {$[91]$} \\
Pure $\mathrm{Mg}$ & $\sim 2-3$ & nanoindentation & $\mathrm{V}=25 \mathrm{~b}^{3}\left(10^{-3}-10^{0} / \mathrm{s}\right)$ & -- & -- \\
Pure $\mathrm{Mg}$ & $>100$ & nanoindentation & $\mathrm{V}=45 \mathrm{~b}^{3}\left(10^{-3}-10^{0} / \mathrm{s}\right)$ & -- & {$[92]$} \\
Pure Mg & 80 & nanoindentation & $\mathrm{V}=28 \mathrm{~b}^{3}\left(10^{-5}-10^{-2} / \mathrm{s}\right)$ & $0.69-1.01^{*}(\mathrm{RT}-573 \mathrm{~K})[94]$ \\
Mg-5Al & 0.045 & tensile & $\mathrm{n}=1.5\left(10^{-7}-10^{-5} / \mathrm{s}\right)$ & $76(\mathrm{RT}-323 \mathrm{~K})$ & {$[95]$} \\
Mg-0.3Bi & 3 & tensile & $\mathrm{m}=0.2-0.3\left(10^{-5}-10^{-4} / \mathrm{s}\right)$ & $85(300-323 \mathrm{~K})$ & {$[76]$} \\
$\mathrm{Mg}-0.3 \mathrm{Mn}$ & 2.8 & tensile & $\mathrm{m}=0.2\left(10^{-5}-10^{-4} / \mathrm{s}\right)$ & $74(300-323 \mathrm{~K})$ & {$[76]$} \\
\hline
\end{tabular}

$b$ : Burgers vector $\left(=3.21 \times 10^{-10} \mathrm{~m}\right.$ in magnesium [160]) ${ }^{*}:$ unit $=\mathrm{eV}$ 


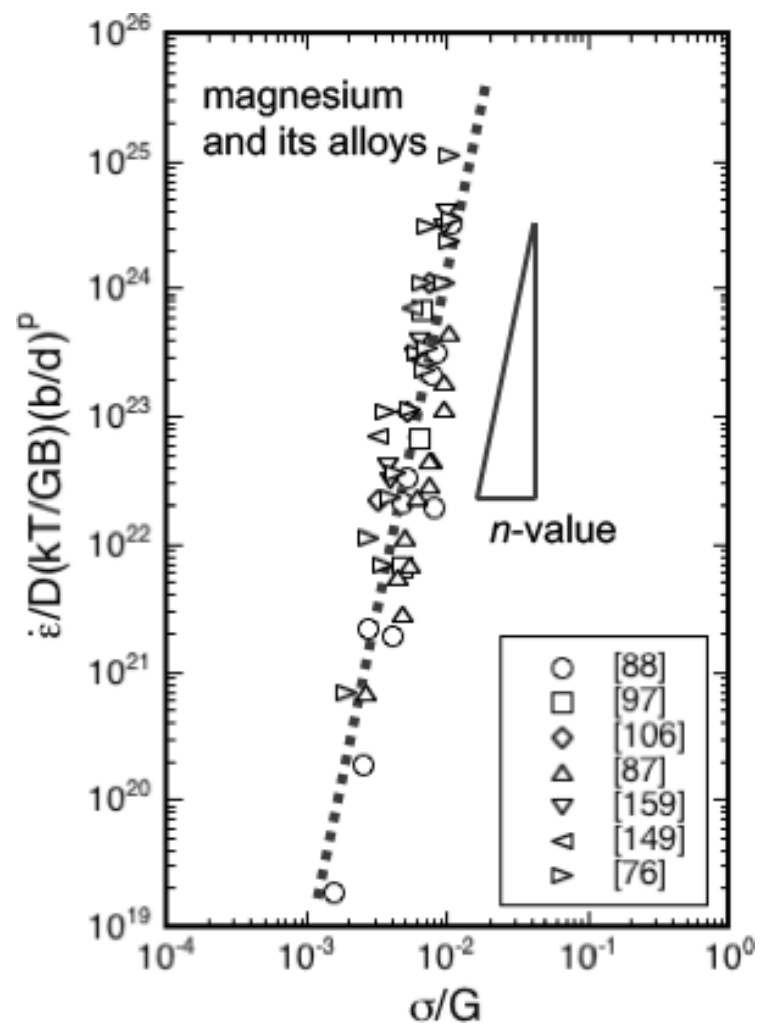

Fig. 11 The variation in $\dot{\varepsilon} / \mathrm{D}(\mathrm{kT} / \mathrm{Gb})(\mathrm{b} / \mathrm{d})^{\mathrm{p}}$ as a function of $(\sigma /$ $\mathrm{G})$ in fine-grained magnesium and its alloys $76,87,88,97,106,149,159)$.

差異がないことから，概ね同じ機構によって，変形が支配さ れていると言える。

\section{4. 結言}

本稿では, マグネシウムに固溶する汎用元素を主な対象と した．最近，粒界すべりを活用した巨大延性化に関して，ビ スマス元素の添加もマンガン元素と同様，または，それ以上 の効果を発揮すると報告がある ${ }^{76,98)}$. 汎用押出加工によって 作製した $\mathrm{Mg}-\mathrm{Bi}$ 合金の破断伸びは, 初期引張ひずみ速度 : $1 \times 10^{-3} \mathrm{~s}^{-1}$ であっても $150 \%$ 以上を示し，超塑性に極めて類 似した挙動を呈する ${ }^{76)}$. しかし, 展伸加工温度域における ビスマス固溶量が小さいことから, $\mathrm{Mg}-\mathrm{Mn}$ 合金等で観察し た添加元素の粒界偏析が起こりにくい. 室温粒界すべりを活 性化させる微視的組織要因が異なることは, 大変興味深い. 一方，マグネシウムに対して固溶しないシリコン元素は (Fig. 1 参照)，容易に $\mathrm{Mg}_{2} \mathrm{Si}$ 金属間化合物を形成する。この 粒子は, 高温変形時の結晶粒粗大化を抑制する組織制御因子

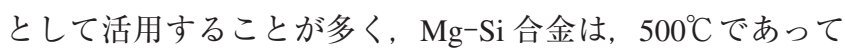
も微細組織構造が維持され, ひずみ速度: $1 \mathrm{~s}^{-1}$ にて破断伸 びが $250 \%$ 以上と高速超塑性を示す ${ }^{99)}$. また，リチウム元素 は，多量に添加することで BCC 相になることも良く認知さ れ，軽量化かつ易成形化を両立させる有望な元素である. $33 \%$ 以上のリチウムを添加した $\mathrm{Mg}-\mathrm{Li}$ 合金は, 水に浮く金 属として有名である ${ }^{100)}$ 。室温延性改善の観点から, HCP 相 と BCC 相の二相からなる超微細結晶粒 $\mathrm{Mg}-\mathrm{Li}$ 合金に至って は, 準静的ひずみ速度下にて $300 \%$ 以上の破断伸びを呈する ことが確認されている101). スカンジウム元素も, 添加濃度
制御により, $\mathrm{HCP}$ 相から BCC 相に結晶構造を変化させる数 少ない元素であり，20\%以上添加することで相変態が起こ る ${ }^{102)}$. 希土類元素でもあるため, マグネシウムとの原子半 径差が大きく, 高強度化にも貢献する元素でもある ${ }^{103)}$. 計 算科学から, チタン元素はマグネシウムと類似した電子構造 を有し, 非底面転位運動の活性化や粒界強化元素として作用 する可能性があると指摘されている104). 現行のプロセス技 術では, Mg-Ti 固溶系合金の作製は不可能であるが, 新規技 術の発展にともない, 夢の合金化となることも期待される. 今後, 人工知能やマテリアルゲノムを活用した材料・合金設 計の創出も夢物語, 近未来の話ではないように思われる. 本 稿が，新規合金設計の一助になれば幸いである。

本稿に対して，建設的なご指摘，ご助言を賜りました吉永 日出男名誉教授 (九州大学), 都留智仁博士 (国立研究開発法 人日本原子力研究開発機構)に深謝いたします。また, 本稿 をまとめるにあたり, 多大なるご助力を頂戴しました大澤嘉 昭博士, 小松玲子氏, 小林康子氏 (いずれも国立研究開発法 人物質・材料研究機構)に重ねて謝意を表します。なお, 本 研究の一部は, 科学研究費補助金 16K06783 および新学術領 域研究 $18 \mathrm{H} 05477$ (ミルフィーユ構造の材料科学), 25102712 (バルクナノメタル)の支援によって得られたものである.

\section{文献}

1) H. Yoshinaga and R. Horiuchi: Trans. JIM 3 (1962) 220-226.

2) H. Yoshinaga and R. Horiuchi: Trans. JIM 4 (1963) 1-8.

3) H. Yoshinaga and R. Horiuchi: Trans. JIM 4 (1963) 134-141.

4) H. Yoshinaga and R. Horiuchi: Trans. JIM 5(1964) 14-21.

5) R. E. Reed-Hill and W. D. Robertson: Acta Metall. 5 (1957) 717-727.

6) R. E. Reed-Hill and W. D. Robertson: Acta Metall. 5 (1957) 728-737.

7) A. Akhtar and E. Teghtsoonian: Acta Metall. 17 (1969) 1339-1350.

8) A. Akhtar and E. Teghtsoonian: Acta Metall. 17 (1969) 1351-1356.

9) W. F. Sheely and R. R. Nash: Trans. Metall. AIME 218(1960) 416423.

10) P. W. Flynn, J. Mote and J. E. Dorn: Trans. Metall. AIME 221 (1961) 1148-1154.

11) B. C. Wonsiewicz and W. A. Backofen: Trans. Metall. AIME 239 (1967) 1422-1431.

12) K. Halada and K. Ijima: Materia Japan 43 (2004) 264-269.

13) The Japan Institute of Metals and Materials: Metals data book, (Maruzen, Tokyo, 2004).

14) T. B. Massalski: Binary Alloy Phase Diagrams, 2nd edition, (ASM International, Materials Park, OH, 1990).

15) L. L. Rokhlin: Magnesium Alloys Containing Rare Earth Metals: Structure and Properties, (CRC Press, 2003)

16) M. Suzuki, H. Sato, K. Maruyama and K. Oikawa: Mater. Sci. Eng. A252 (1998) 248-255.

17) Y. Kawamura, K. Hayashi, A. Inoue and T. Masumoto: Mater. Trans. 42(2001) 1172-1176.

18) E. Abe, Y. Kawamura, K. Hayashi and A. Inoue: Acta Mater. 50 (2002) $3845-3857$.

19) J. A. Yasi, L. G. Hector and D. R. Trinkl: Acta Mater. 58 (2010) 57045713.

20) T. Nogaret, W. A. Curtin, J. A. Yasi, L. G. Hector and D. R. Trinkle: Acta Mater. 58(2010) 4332-4343.

21) S. Ganeshan, S. L. Shang, Y. Wang and Z. K. Liu: Acta Mater. 57 (2009) 3876-3884.

22) T. Tsuru and D. C. Chrzan: Sci. Rep. 5(2015) 8793 (8p)

23) T. Tsuru, Y. Udagawa, M. Yamaguchi, M. Itakura, H. Kaburaki and Y. Kaji: J. Phys. Condens. Matter 25(2013) 022202 (5p).

24) H. Somekawa: Materia Japan 47 (2008) $157-160$

25) D. Ando, J. Koike and Y. Sutou: Acta Mater. 58(2010) 4316-4324.

26) D. Ando, J. Koike and Y. Sutou: Mater. Sci. Eng. A600 (2014) 145152.

27) H. Somekawa, A. Singh and T. Mukai: Philos. Mag. Lett. 89(2009) $2-10$. 
28) V. Kaushik, R. Narasimhan and R. K. Mishra: Mater. Sci. Eng. A590 (2014) 174-185.

29) J. Koike, T. Kobayashi, T. Mukai, H. Watanabe, M. Suzuki, K. Maruyama and K. Higashi: Acta Mater. 51 (2003) 2055-2065.

30) J. Koike, R. Ohyama, T. Kobayashi, M. Suzuki and K. Maruyama: Mater. Trans. 44(2003) 445-451.

31) I. J. Beyerlein, L. Capolungo, P. E. Marshall, R. J. McCabe and C. N. Tome: Philos. Mag. 90 (2010) 2161-2190.

32) J. Wang, I. J. Beyerlein and C. N. Tome: Scr. Mater. 63(2010) 741746.

33) M. R. Barnett: Scr. Mater. 59(2008) 696-698.

34) J. W. Christian and S. Mahajan: Prog. Mater. Sci. 39(1995) 1-157.

35) D. Hull: Acta Metall. 9 (1961) 191-204.

36) M. J. Marcinkosski and H. A. Lipsitt: Acta Metall. 10(1962) 95-111.

37) H. Somekawa, K. Nakajima, A. Singh and T. Mukai: Philos. Mag. Lett. 90 (2010) 831-839.

38) H. Somekawa, T. Inoue and K. Tsuzaki: Philos. Mag. 93 (2013) 45824592.

39) D. A. Basha, H. Somekawa and A. Singh: Scr. Mater. 142(2017) 5054.

40) M. C. Inman and H. R. Tipler: Acta Metall. 6(1958) 73-84.

41) R. A. Mulford, C. J. McMahon, D. P. Pope and H. C. Feng: Metall. Mater. Trans. A7 (1976) 1183-1196.

42) H. Watanabe, A. Owashi, T. Uesugi, Y. Takigawa and K. Higashi: Philos. Mag. 92 (2012) 787-803.

43 ) J. P. Hardorn, K. Hantzschen, S. Yi, J. Bohlen, D. Letzing, J. A. Wollmershauser and S. R. Agnew: Metall. Mater. Trans. A 43(2012) 1347-1362.

44) N. Stanford, G. Sha, J. H. Xia, S. P. Ringer and M. R. Barnett: Scr. Mater. 65 (2011) 919-921.

45) Y. Huang, H. Dieringa and K. U. Kainer: Fat Frac Eng 364(2013) 308-315.

46) M. Bugnet, A. Kula, M. Niewezas and G. A. Botton: Acta Mater. 79 (2014) 66-73.

47) J. D. Robson, S. J. Haigh, B. Davis and D. Griffiths: Metall. Mater. Trans. A 47 (2016) 522-530.

48) D. Zhang, H. Wen, M. A. Kumar, F. Chen, L. Zhang, I. J. Beyerlein, J. M. Schoenung, S. Mahajan and E. J. Laernia: Acta Mater. 120(2016) 75-85.

49) M. P. Seah: J. Phys. F 10(1980) 1043-1062

50) D. McLean: Grain Boundaries in Metals, (Oxford Press, London, 1957).

51) H. W. King: J. Mater. Sci. 1 (1966) 79-90.

52) R. S. Busk: J. M. 188 (1950) 1460-1464.

53) S. Miura, S. Imagawa, T. Toyoda, K. Ohkubo and T. Mohri: Mater. Trans. 49(2008) 952-956.

54) T. Hase, T. Ohtagaki, M. Yamaguchi, N. Ikeo and T. Mukai: Acta Mater. 104 (2016) 283-294.

55) H. Somekawa, A. Singh and T. Inoue: Mater. Sci. Eng. A612(2014) $172-178$.

56) J. F. Nie, Y. M. Zhu, J. Z. Liu and X. Y. Fang: Science 340 (2013) 957-960.

57) Y. Xin, Y. Zhang, H. Yu, H. Chen and Q. Liu: Mater. Sci. Eng. A644 (2015) 365-373.

58) D. Sarker, J. Friedman and D. L. Chen: J. Alloy. Compd. 611(2014) 341-350.

59) D. Drozdenko, P. Dobron, S. Yi, K. Horvath, D. Letzing and J. Bohlen: Mater. Charact. 139(2018) 81-88.

$60)$ C. D. Barnett, A. Imandoust and H. E. Kadiri: Scr. Mater. 146 (2018) 46-50.

61) Y. Cui, Y. Li, S. Sun, H. Bian, H. Hung, Z. Wang, Y. Koizumi and A. Chiba: Scr. Mater. 101 (2015) 8-11.

62) Y. J. Cui, Y. P. Li, Z. C. Wang, Q. Lei, Y. Koizumi and A. Chiba: Int. J. Plast. 99(2017) 1-18.

63) H. Somekawa, H. Watanabe, D. A. Basha, A. Singh and T. Inoue: Scr Mater. 129(2017) 35-38.

64) H. Somekawa and T. Tsuru: Scr. Mater. 130 (2017) 114-118.

65) H. Somekawa, A. Singh, T. Inoue and K. Tsuzaki: Philos. Mag. 94 (2014) 3317-3330.

66) T. Tsuru, H. Somekawa and D. C. Chrzan: Acta Mater. 151(2018) 78-86.

67) T. Mukai, M. Yamanoi, H. Watanabe and K. Higashi: Scr. Mater. 45 (2001) 89-94.

68) S. Sandlobes, Z. Pei, M. Friak, L. F. Zhu, F. Wang, S. Zaefferer, D. Raabe and J. Neugebauer: Acta Mater. 70 (2014) 92-104.

69) H. Somekawa, M. Yamaguchi, Y. Osawa, A. Singh, M. Itakura, T. Tsuru and T. Mukai: Philos. Mag. 95 (2015) 869-885.

70) K. H. Kim, J. B. Jeon, N. J. Kim and B. J. Lee: Scr. Mater. 108(2015) 104-108.

71) S. R. Agnew, M. H. Yoo and C. N. Tome: Acta Mater. 49 (2001) 4277-
4289.

72) H. Somekawa and T. Mukai: Philos. Mag. Lett. 90 (2010) 883-890.

73) T. Matsunaga, T. Kameyama, K. Takahashi and E. Sato: Mater. Trans. 50(2009) 2858-2864.

74) T. Matsunaga, T. Kameyama, K. Takahashi and E. Sato: Mater. Trans. 50(2009) 2865-2872.

75) H. Somekawa and T. Mukai: Mater. Lett. 76 (2012) 32-35.

76) H. Somekawa and A. Singh: Scr. Mater. 150(2018) 26-30.

77) M. A. Meyers, A. Mishra and D. J. Benson: Prog. Mater. Sci. 51 (2006) 427-556.

78) J. Schiotz and K. W. Jacobsen: Science 301 (2003) 1357-1359.

79) J. Schiotz, F. D. Di Tolla and K. W. Jacobsen: Nature391 (1998) 561563.

80) K. S. Kumar, H. Van Swygenhoven and S. Suresh: Acta Mater. 51 (2003) 5743-5774.

81) H. Somekawa, H. Watanabe and T. Mukai: Philos. Mag. 94(2014) 1345-1360.

82) S. Ogata: private communication

83) H. Somekawa and T. Tsuru: Mater. Sci. Eng. A708(2017) 267-273.

84) H. Somekawa, A. Singh and T. Inoue: Mater. Trans. 58(2017) 10891092.

85) H. Somekawa, D. A. Basha and A. Singh: Mater. Sci. Eng. A746 (2019) 162-166.

86) O. D. Sherby and J. Wadsworth: Prog. Mater. Sci. 33(1989) 169-221.

87) H. Somekawa and T. Mukai: Metall. Mater. Trans. A46 (2015) 894902.

88) R. B. Figueiredo, S. Sabbaghianrad, A. Giwa, J. R. Greer and T. G. Langdon: Acta Mater. 122 (2017) 322-331.

89) C. L. Wang, T. Mukai and T. G. Nieh: J. Mater. Res. 24(2009) 16151618.

90) S. Hwang, C. Nishimura and P. G. McCormick: Scr. Mater. 44(2001) 1507-1511.

91) H. J. Choi, Y. Kim, J. H. Shin and D. H. Bae: Mater. Sci. Eng. A527 (2010) 1565-1570.

92) H. Somekawa and C. A. Schuh: Acta Mater. 59(2011) 7554-7563.

93) H. Somekawa and C. A. Schuh: Scr. Mater. 68(2013) 416-419.

94) M. Haghshenas, V. Bhakhri, R. Oviasuyi and R. J. Kiassen: MRS Com 5(2015) pp. 513-518.

95) B. W. Chua, L. Lu and M. O. Lai: Mater. Res. Bull. 41 (2006) 21022110

96) T. Matsunaga, T. Kameyama, S. Ueda and E. Sato: Philos. Mag. 90 (2010) 4041-4054.

97) C. L. P. Silva, A. C. Oliveira, C. G. F. Costa, R. B. Figueiredo, M. F. Leite, M. M. Pereira, V. F. C. Lins and T. G. Langdon: J. Mater. Sci. 52(2017) 5992-6003.

98) H. Somekawa, A. Singh, R. Sahara and T. Inoue: Sci. Rep. 8(2018) $656(9 \mathrm{p})$.

99) M. Mabuchi and K. Higashi: Philos. Mag. A74(1996) 887-905.

100) Y. Kojima: Science and industry 48 (1995) 42-44.

101) K. Edalati, T. Masuda, M. Arita, M. Furui, X. Sauvage, Z. Horita and R. Z. Valiev: Sci. Rep. 7 (2017) 2662 (9p).

102) Y. Ogawa, D. Ando, Y. Sutou and J. Koike: Science 353 (2016) 368370.

$103)$ D. Ando, Y. Ogawa, T. Suzuki, Y. Sutou and J. Koike: Mater. Lett. 161 (2015) 5-8.

104) T. Tsuru: private communication.

105) A. Kumar, G. K. Meenashisundaram, V. Manakari, G. Parande and M. Gupta: J. Alloy. Compd. 695 (2017) 3612-3620.

106) H. Somekawa, A. Singh, T. Mukai and T. Inoue: Philos. Mag. 96 (2016) 2671-2685.

107) Y. Chino, T. Ueda, Y. Otomatsu, K. Sassa, X. Huang, K. Suzuki and M. Mabuchi: Mater. Trans. 52(2011) 1472-1482.

108) A. S. El-Amoush: J. Alloy. Compd. 463 (2008) 475-479.

109) S. C. Kurnaz, H. Sevik, S. Acikgoz and A. Ozel: J. Alloy. Compd. 509 (2011) 3190-3196.

110) H. Wang, K. Zhou, G. Xie, X. Liang and Y. Zhao: Mater. Sci. Eng. A560 (2013) 787-791.

111) S. Seetharaman, C. Blawert, B. M. Ng, W. L. E. Wong, C. S. Goh, N. Hort and M. Gupta: J. Alloy. Compd. 648(2015) 759-770.

112) N. Stanford, I. Sabirov, G. Sha, A. L. Fontaine, S. P. Ringer and M. R. Barnett: Metall. Mater. Trans. A 41 (2010) 734-743.

$113)$ Y. Chino, M. Kado, T. Ueda and M. Mabuchi: Metall. Mater. Trans. A 42 (2011) 1965-1973

114) H. Cao and M. Wessen: Metall. Mater. Trans. A 35(2004) 309-319.

115) H. Somekawa: unpublished data.

116) S. A. Farzadfar, E. Martin, M. Sanjari, E. Essadiqi, M. A. Wells and S. Yue: Mater. Sci. Eng. A534 (2102) 209-219.

117) J. Wei, G. Huang, D. Yin, K. Li, Q. Wang and H. Zhou: Metals 7 (2017) 119 (12p).

118) J. W. Lu, D. D. Yin, G. H. Huang, G. F. Quan, Y. Zeng, H. Zhou and 
Q. D. Wang: Mater. Sci. Eng. A700(2017) 598-608.

119) B. L. Wu, Y. H. Zhao, X. H. Du, Y. D. Zhang, F. Wagner and C. Esling: Mater. Sci. Eng. A527 (2010) 4334-4340.

120) G. H. Huang, D. D. Yin, J. W. Lu, H. Zhou, Y. Zeng, G. F. Quan and Q. D. Wang: Mater. Sci. Eng. A720 (2018) 24-35.

121) A. Kula, X. Jia, R. Mishra and M. Niewczas: Metall. Mater. Trans. B46 (2016) 3333-3342.

122) B. Q. Shi, R. S. Chen and W. Ke: Mater. Sci. Eng. A560(2013) 6270 .

123) L. Gao, R. S. Chen and E. H. Han: J. Alloy. Compd. 472 (2009) 234240.

124) A. Singh, H. Somekawa and T. Mukai: Mater. Sci. Eng. A698 (2017) 238-248.

125) S. Sandlobes, S. Zaefferer, I. Schestakow, S. Yi and R. Gonzalez-Martinez: Acta Mater. 59(2011) 429-440.

126) I. Kawarada, R. Zheng, A. Shibata, H. Somekawa, S. Ogata and N. Tsuji: Magnesium Technology 2017, (2017) 283-287.

127) C. D. Li, X. J. Wang, W. Q. Liu, K. Wu, H. L. Shi, C. Ding, X. S. Hu and M. Y. Zheng: Mater. Sci. Eng. A597 (2014) 264-269.

128) H. Somekawa, Y. Osawa and T. Mukai: Scr. Mater. 55(2006) 593596.

129) C. J. Boehlert: J. Mater. Sci. 42 (2007) 3675-3684.

130) S. Wei, T. Zhu, M. Hodgson and W. Gao: Mater. Sci. Eng. A550 (2012) 199-205.

131) X. Zeng, Y. Liu, W. Huang, G. Zeng and G. Zhou: Mater. Sci. Eng. A571 (2013) 150-154.

132) B. Langelier, A. M. Nasiri, S. Y. Lee, M. A. Gharghouri and S. Esmaeili: Mater. Sci. Eng. A620 (2015) 76-84.

133) Y. Du, M. Zheng, X. Qiao, D. Wang, W. Peng, K. Wu and B. Jiang: Mater. Sci. Eng. A656 (2016) 67-74.

134) Q. Kang, H. Jiang, Y. Zhang, Z. Xu, H. Li and Z. Xia: J. Alloy. Compd. 742 (2018) 1019-1030.

135) S. Wei, T. Zhu, M. Hodgson and W. Gao: Mater. Sci. Eng. A585 (2013) 139-148.

136) H. Somekawa, Y. Osawa, A. Singh and T. Mukai: J. Mater. Res. 23 (2008) 1128-1135.

137) B. Q. Shi, R. S. Chen and W. Ke: Mater. Sci. Eng. A560(2013) 6270.

138) Z. Li, N. Huang, J. Zhao and S. J. Zhou: Mater. Sci. Technol. 29
(2013) 140-147.

139) Y. Qiao, X. Wang, Z. Liu and E. Wang: Mater. Sci. Eng. A568 (2013) 202-205.

140) M. Shanthi, P. Jayaramanavar, V. Vyas, D. V. S. Seenivasan and M. Gupta: J. Alloy. Compd. 513 (2012) 202-207.

141) J. Herenguel and P. Lacombe: Metaux 11(1936) 185-194.

142) J. A. Chapman and D. V. Wilson: J. Inst. Metals 91 (1962-3) 39-40.

143) D. V. Wilson: J. Inst. Metals 98 (1970) 133-143.

144) Z. Yu, A. Tang, J. He, Z. Gao, J. She, J. Liu and F. Pan: Mater. Charact. 136 (2018) 310-317.

145) L. Zhong, J. Peng, M. Li, Y. Wang, Y. Lu and F. Pan: J. Alloy. Compd. 661 (2016) 402-410.

146) J. Bohlen, S. Yi, D. Letzig and K. U. Kainer: Mater. Sci. Eng. A527 (2010) 7092-7098.

147) K. Suzuki, Y. Chino, X. Huang, M. Yuasa and M. Mabuchi: Mater. Trans. 54(2013) 392-398.

148) H. Somekawa, D. A. Basha and A. Singh: Mater. Sci. Eng. A730 (2018) 355-362.

149) H. Somekawa, A. Kinoshita and A. Kato: Mater. Sci. Eng. A697 (2017) 217-223.

150) Z. Yu, A. Tang, Q. Wang, Z. Gao, J. He, J. She, K. Song and F. Pan: Mater. Sci. Eng. A648(2015) 202-207.

151) D. V. Wilson and J. A. Chapman: Philos. Mag. 8(1963) 1543-1551.

152) N. Ono, R. Nowak and S. Miura: Mater. Lett. 58(2003) 39-43.

153) J. A. Sharon, Y. Zhang, F. Mompiou, M. Legros and K. J. Hemker: Scr. Mater. 75 (2014) 10-13.

154) Y. Li and M. Enoki: Mater. Trans. 48(2007) 1215-1220.

155) C. H. Caceres and A. H. Blake: Mater. Sci. Eng. A462(2007) 193196.

156) F. E. Hauser, P. R. Landon and J. E. Dorn: Trans. Metall. AIME 206 (1956) 589-593.

157) G. S. Rao and Y. V. R. K. Prasad: Metall. Mater. Trans. A13 (1982) 2219-2226.

158) H. Somekawa and T. Mukai: Scr. Mater. 53(2005) 1059-1063.

159) C. H. Cacers, G. E. Mann and J. R. Griffiths: Metall. Mater. Trans. A42 (2011) 1950-1959.

160) H. J. Frost and M. F. Ashby: Deformation-mechanism Map, (Pergamon Press, Oxford, 1982). 